\title{
Seasonal Variation of Trihalomethanes Levels in Greater Cairo Drinking Water
}

Eglal MR Souaya ${ }^{1}$, Ali M Abdullah ${ }^{2 *}$ and Mohamed Mossad ${ }^{3}$

${ }^{1}$ Department of Chemistry, Faculty of Science, Ain Shams University, Egypt

${ }^{2}$ Holding Company for Water and Wastewater, $O$ and $M$ Sector, Egypt

${ }^{3}$ Holding Company for Water and Wastewater, Reference Laboratory, Egypt

\begin{abstract}
The formation of carcinogenic Trihalomethanes (THMs) in the process of water disinfection by chlorine has raised concerns in the scientific community. This study aims to determine the levels of THMs in Greater Cairo drinking water over year of the study and compare it with the regulation in the Egypt law (458/2007), and the World Health Organization. The THMs concentration was measured in five different locations during 2014. The results indicate that the seasonal variation is below the critical values stipulated in the state, WHO and Egyptian regulations (seasonal average $45.14 \pm 9.23 \mu \mathrm{g} / \mathrm{l})$. In conclusion, it can be inferred that the concentration of THMs in the drinking water of Greater Cairo is not hazardous to human health.
\end{abstract}

Keywords: Drinking water; Greater Cairo; Trihalomethanes

\section{Introduction}

Chlorine disinfection processes and other oxidation processes to inactivate harmful microorganisms are questioned by the potentially toxic by-products formed during disinfection. Chloroform, a Trihalomethane produced during chlorination, was shown to be a carcinogen for mice and rats [1]. THMs are the most commonly occurring and toxic DBPs found in chlorinated waters [2]. There is a variety of disinfection methods being use worldwide for treatment, but chlorination is the most common method among these methods. Water disinfection with chlorine improves the hygienic quality of water by eliminating waterborne bacterial pathogens such as dysentery and diarrhea diseases, cholera, typhoid fever, hepatitis A, etc. Residual chlorine can protect water from secondary pollution in the water network; also Chlorine application is simpler than other disinfectants. The usage of chlorine consequences a wide range of organic compounds (DBPs), which occur due to the reaction between chlorine with natural organic compounds, mainly humic substances [3]. One of the main groups of DBPs is THMS compounds. Clark et al. suggested that; more than 500 DBPs have been identified in tap water $[4,5]$. Chloroform, a DBP was first identified in the finished drinking water in 1974 in the Netherlands by Rook and in the United States by Bellar et al. [6].

A statistical correlation was developed to predict the concentration of chloroform formation as function of $\mathrm{pH}$, temperature and distance (near or far) between a reservoir and a point of interest in the distribution system. This correlation is qualitative in the sense that distance and time are not included implicitly in it [6].

Many studies cited that the generated a multiple regression model for predicting THMs level in the finished water leaving a treatment plant. The correlation implies that THMs formation is higher in summer through autumn and lower in winter through spring.

Sokeng et al. described a mathematical model that applies second order kinetics to predict the chlorine residuals and demonstrates that THMs formation can be characterized as a function of chlorine demand [7]. The parameters of this model are correlated as a function of $\mathrm{pH}$, TOC, temperature and chlorine residual. The formation of THMs in drinking water has been shown to be a function of various water quality parameters and chlorination conditions. THMs formation is one of the slowest known reactions in water treatment and a number of important factors influence this reaction. These include residence time, $\mathrm{pH}$, temperature, bromide ion concentration, chlorine dosage, type of organic precursor and the Total Organic Carbon (TOC).

In the present paper, the overall objective is to monitoring and understanding of the effect of water parameters on THMs formation in Greater Cairo region drinking water.

\section{Materials and Methods}

The city of Cairo is capital of Egypt and has about 1500000 inhabitants. Even though it has sufficient water resources and permanent water flows (river Nile). The statistics show that the average amount of water per inhabitant is about 200-250 liters per day. The drinking water in Cairo is disinfected with gaseous chlorine without any kind of special treatment.

The experimental part of the research was done in the laboratories of the Holding Company for Water and Wastewater. Five sample points were selected in the city of Cairo and during the study 2014 the drinking water samples were analyzed.

The water samples were collected from five water treatment plants and its distribution systems, Water samples at the specified locations were collected in $60 \mathrm{ml}$ glass bottles (amber glass), which were filled without passing air bubbles through the sample. Before sampling, a solution of sodium thiosulfate was added to the amber bottles to eliminate any remaining residual chlorine and to stop further THM formation. Each glassware used was previously washed with phosphate-free detergent, rinsed with ultrapure water (Milli-Q) and acetone (HPLC grade). Then, it was placed in an oven at $150^{\circ} \mathrm{C}$ for two hour and cooled at room temperature.

Samples were prepared by extracting $10 \mathrm{ml}$ of water with $2 \mathrm{ml}$ of pentane by shaking for $2 \mathrm{~min}$ in a separation funnel of $25 \mathrm{ml}$. Phase separation occurred within $3 \mathrm{~min}$ and the upper phase was collected into $2 \mathrm{ml}$ vials having screw caps with PTFE septa. THM measurements

*Corresponding author: Ali M Abdullah, Holding Company for Water and Wastewater O and M Sector, Egypt, Tel: 002-012-292-480-37; E-mail: dr2252000@dr.com

Received February 20, 2015; Accepted March 19, 2015; Published March 24 2015

Citation: Souaya EMR, Abdullah AM, Mossad M (2015) Seasonal Variation of Trihalomethanes Levels in Greater Cairo Drinking Water. Mod Chem appl 3: 149 doi:10.4172/2329-6798.1000149

Copyright: (c) 2015 Souaya EMR. This is an open-access article distributed under the terms of the Creative Commons Attribution License, which permits unrestricted use, distribution, and reproduction in any medium, provided the original author and source are credited. 
were made using a gas chromatograph equipped with electron capture detector (GC-ECD, Varian, Model CP-3800). Chromatographic separation was accomplished with a capillary column DB-5 (J and W Scientific Inc./Agilent Technologies, $30 \mathrm{mv} \times 0.25 \mathrm{~mm} \times 0.25 \mu \mathrm{m})$. The GC oven temperature program was as follow: initial temperature in $40^{\circ} \mathrm{C}$ for $2 \mathrm{~min}$ and then ramped $10^{\circ} \mathrm{C}$ per min until $150^{\circ} \mathrm{C}$. Carrier gas (N2) at a flow rate of $0.8 \mathrm{ml} \mathrm{min}^{-1}$ and split ratio of 1:10 was used in each experiment. It was injected $2 \mu \mathrm{l}$ of each sample in the capillary column. For the calibration curve, standard solutions of $\mathrm{CHCl}_{3}$ (Supelco Inc., 98.8\%), $\mathrm{CHBrCl}_{2}$ (Supelco Inc., 99.9\%), $\mathrm{CHBr}_{2} \mathrm{Cl}$ (Supelco Inc., 99.0\%), and $\mathrm{CHBr}_{3}$ (Supelco Inc., 99.9\%) in concentrations ranging from 0.05 to $100 \mu \mathrm{g} / \mathrm{l}$ in ultrapure water (Table 1 ).

\section{Result and Discussion}

The experimental results have been presented in Figures 1-6. The concentration of THMs on the sample points vary from one month to another at a low rate. Therefore, the average values of THM concentrations during the present study in Fustat district (South of Cairo) were $45.14 \mu \mathrm{g} / \mathrm{l}$, respectively, the minimum value observed during December 2014 and the maximum value observed during July 2014 as shown in Figure 1. The average values of THM concentrations during the present study in Rod El-Farag district (middle of Cairo) were $46.28 \mu \mathrm{g} / \mathrm{l}$, respectively, the minimum value observed during March 2014 and the maximum value observed during October 2014 as shown in Figure 2.The average values of THM concentrations during the present study in Shoubra district (North of Cairo) were $51.40 \mu \mathrm{g} / \mathrm{l}$, respectively, the minimum value observed during May 2014 and the maximum value observed during October 2014 as shown in Figure 3.

The average values of THM concentrations during the present study in El-Obour district (East of Cairo) were $44.32 \mu \mathrm{g} / \mathrm{l}$, respectively, the minimum value observed during May 2014 and the maximum value observed during October 2014 as shown in Figure 4. The average values of THM concentrations during the present study in El- Roda district (East of Cairo) were $49.95 \mu \mathrm{g} / \mathrm{l}$, respectively, the minimum value observed during March 2014 and the maximum value observed during June 2014 as shown in Figure 5.

All samples collected from five districts had THM less than the Egyptian regulation limits $(100 \mu \mathrm{g} / \mathrm{l})$.

In 1988, Ali et al. found that THM in drinking water of Kuwait (from rooftop tanks) averaged $25.6 \pm 9.1 \mu \mathrm{g} / \mathrm{l}$ with a maximum recoded value of $50.5 \mu \mathrm{g} / \mathrm{l}$. the THM formation generally favored by high temperature, chlorine residue and source natural organic matters composition (NOMs) [8-10] .

The observed seasonal variation of THMs was consistent with earlier studies reported maximum THM formation in summer [11]. $\mathrm{CHCl}_{2} \mathrm{Br}$ and $\mathrm{CHClBr}_{2}$ exhibit inconsistent higher mean seasonal variations in winter than summer as indicated in Figures 1-5.

These higher mean values in winter can be attributed to characteristics of natural organic matter and changes in the nature of THM precursors in the source water [12-15].

\begin{tabular}{|c|c|c|}
\hline Compound & WHO (2012) & Egypt (2007) \\
\hline Chloroform & 0.300 & 0.300 \\
\hline Bromodichloromethane & 0.100 & 0.100 \\
\hline Dibromochloromethane & 0.60 & - \\
\hline Bromoform & 0.100 & 0.100 \\
\hline Total Trihalomethanes & 0.100 & 0.100 \\
\hline
\end{tabular}

'The maximum permissible limits

Table 1: Standards/recommending guidelines for THMs $(\mathrm{mg} / \mathrm{l})$ in the world jurisdictions.

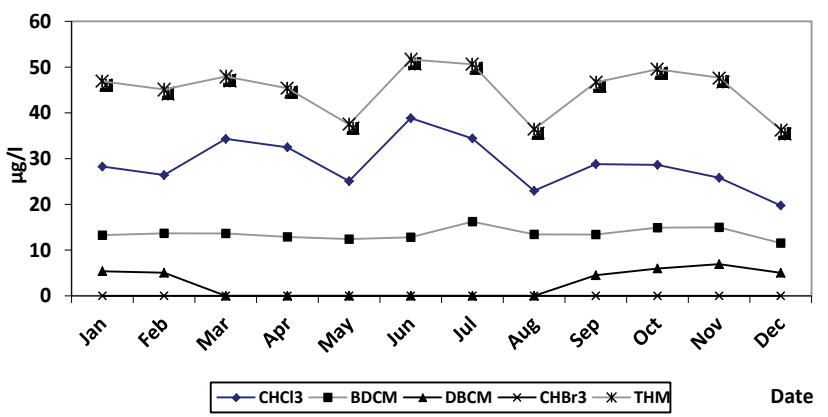

Figure 1: THM analysis of Fustat WTP during the period of study.

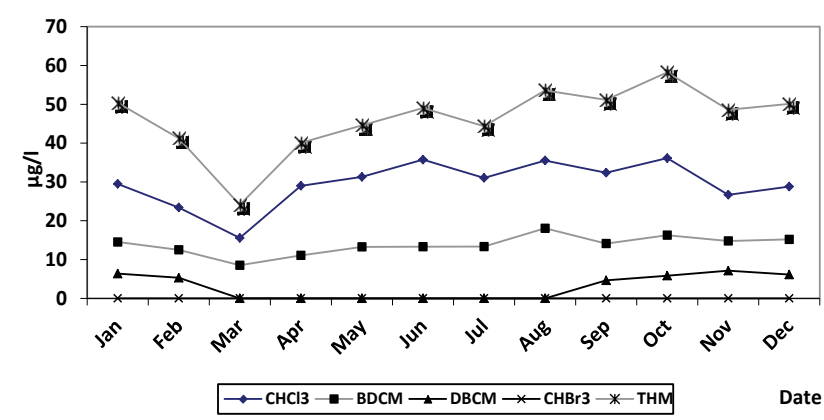

Figure 2: THM analysis of Rod El Farag WTP during the period of study.

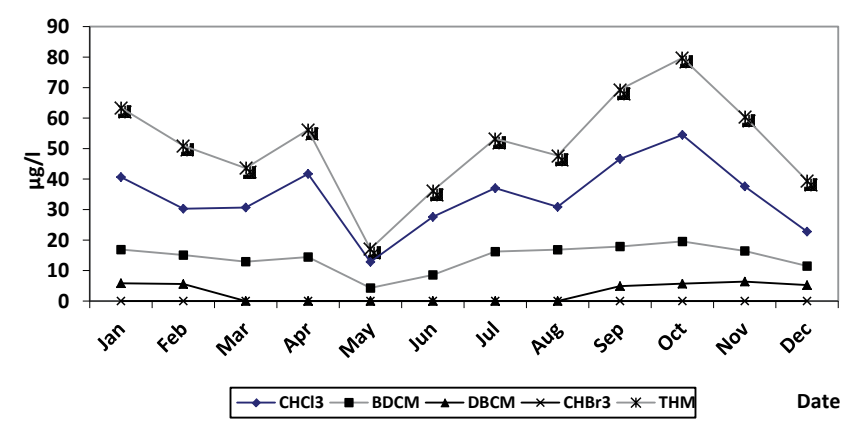

Figure 3: THM analysis of Shobra-El Khema WTP during the period of study

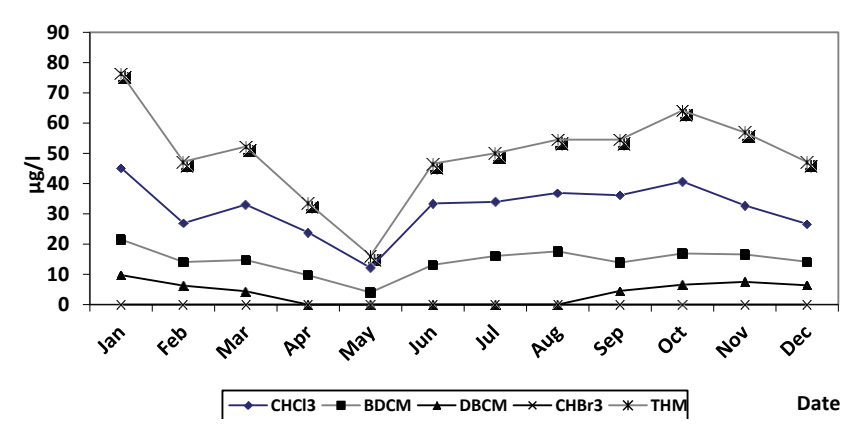

Figure 4: THM analysis of El Obour WTP during the period of study. 


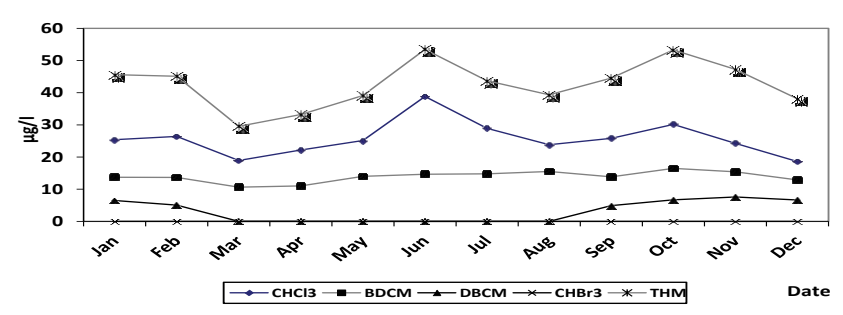

Figure 5: THM analysis of EI Roda WTP during the period of study.

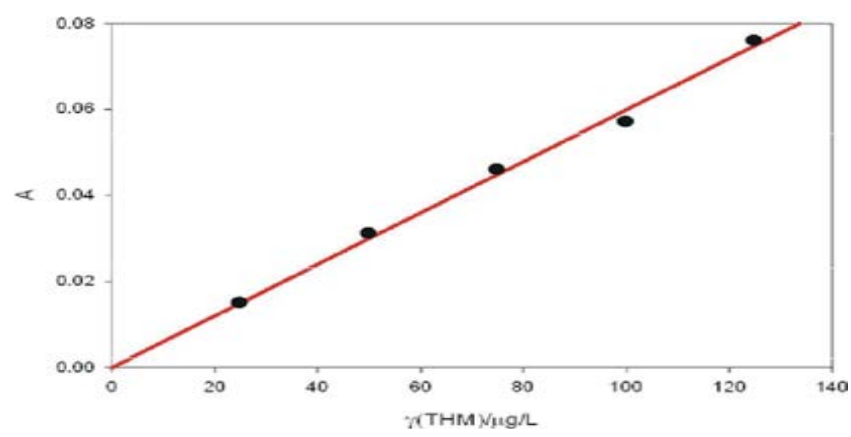

Figure 6: Calibration curve for THMs determination, May 2014.

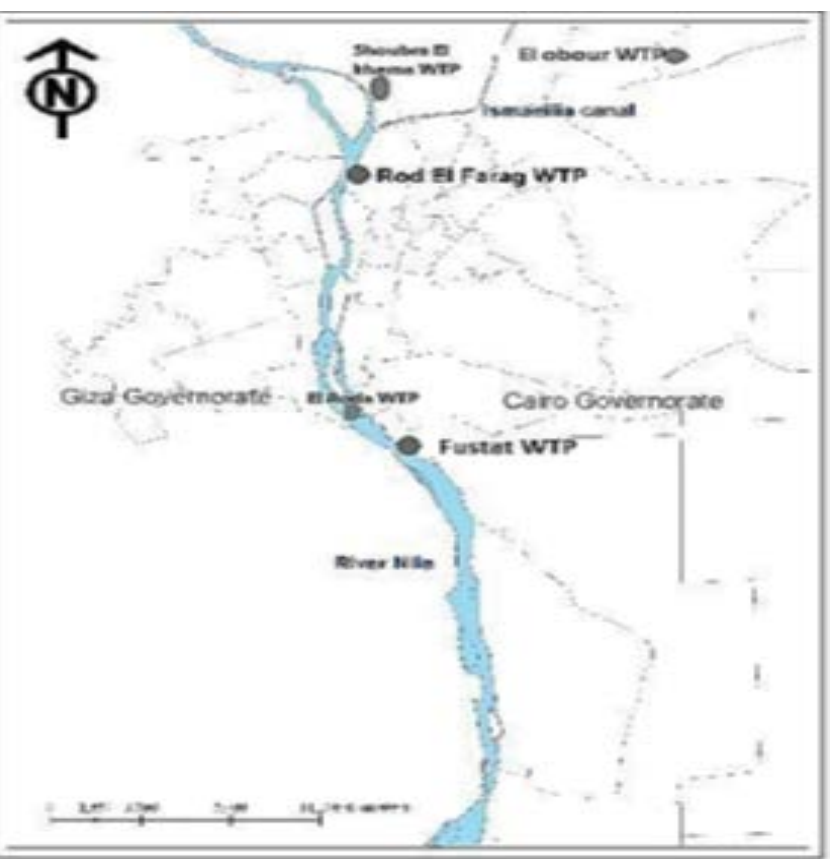

Sampling Sites (the map explain the sampling sites of THM in Greater Cairo).

\section{Conclusion}

The presence of THMs in the drinking water in the last decades has caused great worries since these components can cause cancer in humans. The monitoring of the THMs formation is crucial in order to make sure that the drinking water remains at the acceptable security levels. Therefore, the actions to reduce the THMs should be encouraged and there should be no compromise when it comes to the water disinfection. The variation of the THMs level shows the effect of different factors on their formation under the conditions of water chlorination as well as the performance of enterprises that deal with water treatment and management.

Present study found considerable variation in THM concentration between the cold and hot seasons. Some locations experiencing elevated concentrations near to WHO and USEPA's THM regulations and require a systematic monitoring program to carefully observe the THM's levels. The THM level following the general trend of higher concentrations in summer compared to winter with large variations in the concentration levels. It is difficult identify the principle parameters driving the THM formation for all the seasons in the presence of complex nature of source water NOMs matrix. A comprehensive monitoring program of the THM in the urban water supply is recommended to facilitate the evaluation of principle factors causing elevated levels of THM which may cause adverse health effects.

\section{References}

1. World Health Organization (2001) Sustainability and optimization of Water supply and sanitation services.

2. Department of Environment and Labour, Water Resources Management Division (2000) Trihalomethane Levels in Public Water Supplies of Newfoundland and Labrador. Government of Newfounland and Labrador Canada, Project, pp: 15-20.

3. Nikolaou A, Lekkas T (2001) The role of natural organic materials during formation of chlorination by-products: a review. Acta Hydrochimica et Hydrobiologica 29: 63-77.

4. Clark R, Pourmoghaddas H, Wymer L, Dressman R (1996) Modeling the kinetics of chlorination by-products formation: the effects of bromides. SRTaqua 45: $112-119$.

5. Rook JJ (1974) Formation of Haloforms during Chlorination of Natural Waters. J Water Treat Examin 23: 234-237.

6. Bellar TA, Lichtenberg JJ (1974) Determining volatile organics at microgramper-liter levels by gas chromatograph. J Am Water Works Assoc 66: 739-744.

7. Sokeng SD, Lontsi D, Moundipa PF, Jatsa HB, Watcho P et al. (2007) Hypoglycemic Effect of Anacardium occidentale L. Methanol Extract and Fractions on Streptozotocin-induced Diabetic Rats. GJP 1: 01-05.

8. Contu A, Bordigoni M, Sarritzu G, Premazzi G, Pudda M, et al. (1990) Trihalomethanes in the water supplies of Sardinia, Italy. Bull Environ Contam Toxicol 44: 805-812.

9. Hoehn RC, Barnes DB, Thompson BC, Randall CW, Grizzard TZ, et al. (1980) Algae as sources of trihalomethane precursors. J Amer Water Wks Assoc 72: 344-350.

10. Symons JM, Bellar TA, Carswell JK, De Marco J, Kropp KL, et al. (1975) National organics reconnaissance survey for halogenated organics. J Am Water Works Assoc 67: 634-647.

11. Sadiq R, Rodriguez MJ (2004) Disinfection by-products (DBPs) in drinking water and predictive models for their occurrence: a review. Sci Total Environ 321: $21-46$.

12. Jashari N (2010) Manual for drinking water. Tetova Water Supply, Tetova, pp: 14-18.

13. Huang JYC, Smith GC (1984) Spectrophotometric Determination of Total Trihalomethanes in Finished Waters. Journal AWWA 76: 168-171.

14. Pauzi MA, Yew CH, Ramli MS, Ali R (2003) Trihalomethanes (THMs) in Malaysian Drinking Water. Malaysian Journal of Chemistry 5: 056-066.

15. Government of the Republic of Macedonia (2004) State Drinking water regulation. Official gazette No. 57/2004, pp: 24. 